\title{
Flood Control and Drainage System of Espana Boulevard in Metro Manila
}

\author{
Tomas U. Ganiron Jr \\ IAENG, Hongkong \\ College of Architecture, Qassim University, Buraidah City \\ Tomasuganironjr@gmail.com
}

\begin{abstract}
The study of drainage system in Metro Manila specifically along Espana Boulevard will bring major benefits. As the improvement of the drainage system, it reduces the damages to the houses and public facilities. Minimize the loss of public and private properties will contribute greatly to the improvement and standard of living to the stabilization of people's livelihood and the serious congestion resulting from the long flooding in Metro Manila. Flooding is a perennial problem in Metro Manila, various flood and drainage system projects have been implemented in Metropolis in the last two decades, but it seems only a little have been gained because the flood problems will persist. Flood control and drainage system has yet effectively address due to the inadequate capacity of existing drainage channels in conveying storm water to the dumping stations. The drainage improvement measure has been hampered by the very limited information in the present conditions of existing drainage channels.
\end{abstract}

Keywords: Drainage channels, drainage system, flood control, pumping station, rainfall

\section{Introduction}

The Philippine Atmospheric, Geophysical and Astronomical Service Administration (PAGASA) defines "flood" as an abnormal progressive rise in the water level of a stream that may results in the overflowing of water on its normal confines of the stream with the subsequent inundation of areas which are not normally submerge. In simple forms, flood occurs whenever a stream or river overflows its banks, more often, it is a subsequence of continuous and excessive rainfall brought about by South West monsoon or typhoon. Generally, floods also occur in low-lying areas that serve as natural depositional environments. In Luzon, notable examples are the Agno River, the Pampanga river basin, the Marikina River and the Pasig delta where the city of Manila was built.

Based on the analysis of the present conditions of drainage laterals in Manila and suburbs were made considering the run-off and flow capacity of existing drainage channels, the flow of direction in the drainage laterals, interconnectivity within each drainage block, and topography of the catchment area. The analysis results show the discharge and flow capacity of the drainage laterals in manila and suburbs to be inadequacy of several channels for 2 year and 10 year floods [1].

Because of the inadequacy capacity of drainage storm water of the most drainage laterals, drainage mains and open channels, the low-lying areas of Manila and suburbs such as Sampaloc (North of the Pasig river) and San Antonio-Palanan Pio Del Pilar (South of the Pasig River) become prone to flooding. The limited flow capacity of drainage channels was found out to be the caused by one or several combinations of the following: undersized drainage channels, unevenly laid slope of the conduit, irregular channel profile inconsistent drain size, clogged manholes, 
sediments deposits along the drainage channels, overflowing of the estuary, flood water spilling to neighboring areas and submerged crown elevation at the outlet[1]. Also contribute the significant reduction of their carrying capacity, and thereby aggravating the problem of flooding in the most part of Manila and suburbs area: the encroachment of estuary and waterways by informal settlers, uncoordinated infrastructure development activities by various public utility agencies, indiscriminate disposal of garbage, and increased run-off resulting from rapid urban development.

Considering that the flooding problem is regional in the scope and involves several closely connected drainage blocks, drainage mains, estuary, and pumping stations that is necessary to comprehensive drainage planning should be undertaken through a master plan study. With the view towards formulating long-term solutions to the flooding problem, the master plan should come up with a balance or combination of structural and nonstructural measures. The structural ones should include the following: construction of additional drainage channels, improvement of the estuary, and rehabilitation and improvement of existing drainage mains such as rerouting of flows to less stressed lines, compartmentalization of drainage blocks to reduce the problems areas into manageable levels, or possibly redesign or reconstruction of the whole drainage system.

The study of drainage system along Espana Boulevard aims to improve the health of the society, safety and quality of life. It helps to reduce flood in generally affected areas, and reduces the damages caused by flood. In achieving these goals, adequate drainage facilities, a proper place for dumping the garbage, better relocation of the squatters, and a comprehensive study plan for the assessment of this plan is a top priority.

The Manila Metropolitan areas suffer from flood in every rainy season, which is mainly attributed to the malfunctioning of the existing drainage system due to the adequate maintenance under these circumstances. The government plans to improve the existing drainage system. The availability of proper equipment is indispensable to accomplish the above objectives in this sense, this projects plays an important as a pilot project providing importance in drainage problem in Espana. The project includes the procurement of equipment and transfer of technology required for the operation and implementation. The study shall confirm the maintenance of the pumping station and floodgates to determine if there is a need for the repair and rehabilitation of the pumping station and floodgates equipment.

\section{Related Literature}

The existing drainage system in Manila and suburbs are is composed of closed principal channels called "drainage mains" or the "outfalls", and open channels called "creeks" or the "estuary", secondary or the tertiary drainage channels called "drainage laterals", and pumping stations. The initial drainage construction works were based on the plan for the drainage of Manila and suburbs areas. A master plan prepared in 1952 by the former Bureau of Public Works (BPW), subsequent system improvements were based on lateral revisions of the 1952 master plan [1,2]. One of such revisions was made in 1978 under the "Manila and suburbs flood control projects", another was made in 1984 under" Metro Manila integrated urban drainage and flood control master plan" of the Ministry of Public Works and Highways now it is called the Department Public Works and Highways (DPWH) [3].

The DPWH today is in charge of the installation and maintenance of drainage facilities located along national roads. The Local Government Units (LGU), on the other hand, are responsible for the construction and maintenance of drainage facilities located along cities or municipal roads. The DPWH has installed 35 
drainage mains (outfalls) along the national roads of Metro Manila, which all together have a total length of 34 kilometers [3],[5]. There is no consolidated data on drainage facilities constructed by the various LGU but most of the roads within Manila and suburbs have drainage laterals installed.

Manila suburbs which are being serviced by 15 pumping stations for draining the storm water to the Pasig River or Manila bay [4]. All these stations are operated and maintained by the DPWH and were designed for draining storm water of a 10 years return period of these pumping stations. Seven (7) were composed and become operational between 1976 and 1977 through financial assistance by the Overseas Economic Cooperation Fund (OECF) [5, 7]. These seven stations shown in Figure 1 are Valencia, Quiapo, Pandacan, Aviles-Sampaloc, Paco, Sta. Clara, and Tripa De Gallina [6].

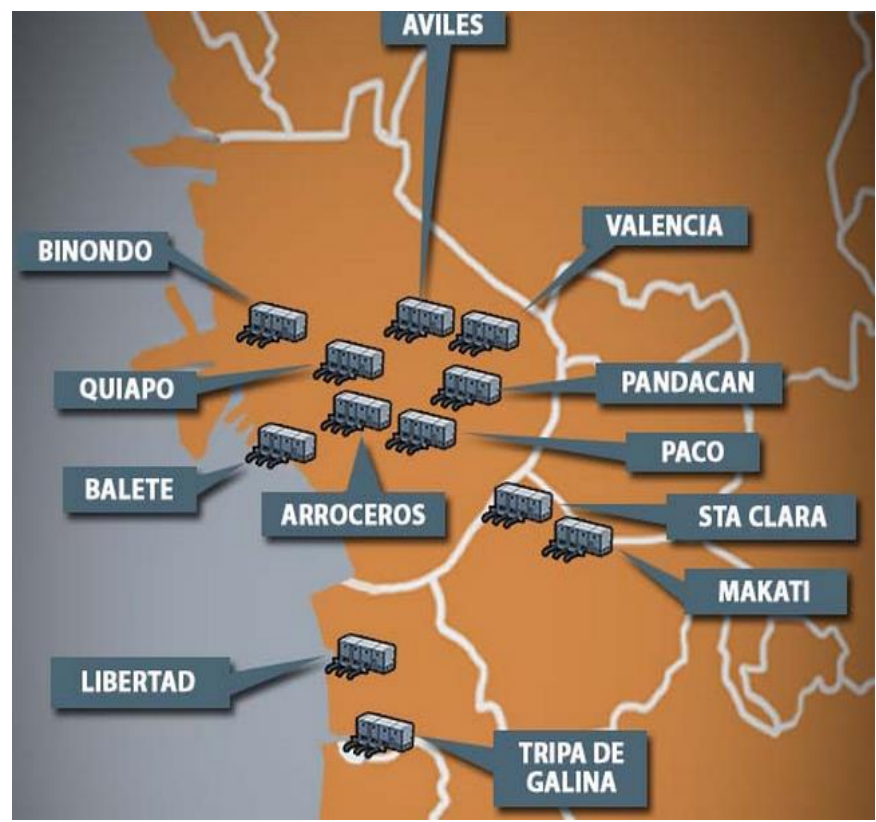

Figure 1. Water Pumping Stations

Procurements of the required equipment for three (3) of the 15 stations for draining the storm water namely: Libertad, Binondo and Makati pumping stations, was individually undertaken during 1979 to 1985 [7, 8]. The export-import bank (EXIM bank) of Japan financed the equipment procurement. The construction of 5 remaining stations namely: Vitas, Balut, Escolta, san Andres and Balete were made possible through the financial loan assistance from OECF Japan. The said construction started in 1994 and it was completed in 1998 [8].

To address the increasing accumulation of sediments and garbage in drainage channels, The DPWH carried out the project for retrieval of flood prone areas in Metro Manila. The Phase 1 of the project was implemented in 1990 and the Phase 2 is in 1994 for this project, which was also meant to complement the gains made in other flood control projects [7,8]. The GOP sought and obtained GOP helps in getting the necessary equipment through GOJ general grant program round. In given this background, the present conditions of drainage laterals in Manila and suburbs were ascertained through the field survey. The various data sets generated from the survey entered in the lateral database, together with the location maps, they collectively form the basis for the analysis of existing conditions of drainage laterals and drainage blocks in Manila and suburbs [8]. 
To determine the adequacy of existing mains and laterals in relation to the blocks being drained, the first requirement is to estimate the storm run-off at the point of interest. Run-off may be estimated using the Rational formula where $\mathrm{Q}=$ discharge $(\mathrm{m} 3 / \mathrm{s}), \mathrm{C}=$ run-off coefficient, I=rainfall intensity $(\mathrm{mm} / \mathrm{hr}$.), $\mathrm{A}=$ catchment area (ha) caught as it falls on the area as overflow from the other areas. Rainfall intensity is thus an important factor.

In evaluating the adequacy of drainage channel, the blocks to be drained, and a non-uniform flow is adopted in the calculation of flow capacity. A pressure flow condition is considered in cases where a submerged outfall is likely to occur. These are the following adopted assumptions: roughness coefficient (open channels) = 0.025 , roughness coefficient (box culvert) $=0.015$, hydraulic boundary condition gravity system $=$ EL. 11.30 meters for Manila bay tide pumped system $=$ pumping station [8].

The channel profiles are prepared using the lateral database and by first sequencing the manhole data are retrieved and tabulated, then transferred to MS Excel to plot the longitudinal profile. An accompanying figure reflects the bed elevation, deposition level, water level, channel top elevation and ground elevation.

The delineation of drainage blocks in this study resembles the delineation of DPWH drainage blocks, which is based on the pumping service area. It should be noted here, however that drainage areas presented in previous studies were design drainage areas delineated from old 1:50000-scale topographic maps, not from the relatively never 1:10000-scape maps which came out only in the early nineties. Accurate delineation of these drainage areas, which relatively are almost flat, is difficult to achieve using 1:50000-scale topographic maps [7, 9]. In this study, the digital location map drainage areas for the pumping stations are delineated from the 1:2500 scale digital location maps [7]. The delineation made considered not only the topography but also the interconnectivity of drainage lines from the farthest point to the pumping station. As shown by this study, the delineation of drainage blocks for a 10 year flood vanishes because the flow capacities of drainage channels for draining the floodwaters to spill over to a neighboring drainage blocks, thus resulting to wide-scale flooding of low-lying drainage blocks [8].

Surface run-off generally follows the topography and thus collected by a system of street inlets and tertiary roadsides drains. It is then conveyed into the drainage mains and laterals to the disposed and ultimately to Pasig river or Manila bay either by gravity or pumping.

As mentioned above, because of the insufficient flow capacity of drainage channels, surface run-off of 10-years flood likewise flows along roadways following the topography from drainage block to drainage block. The flow continuous up to a low lying drainage blocks where two drainage blocks may share the same estuary, thus stressing or putting pressure on the pumping station $[9,10]$.

Whether the capacities of pumping stations are inadequate or not after taking note of the difference between the drainage areas determined in this study and the design drainage further details.

\section{Research Methodology}

The researcher employed a descriptive method of research in the study. The focus of concern of the research is the study of the effectiveness of drainage system along Espana Boulevard. Every year, its' residents and public is affected by floods and the problem is causing a big concern among them. Accidental sampling under the category of non-probability sampling was adapted. The researcher went through the area within the subject and conducted a survey to those who gave them a chance. Fifty respondents who are making a living nearby the location of the subject and 
also the everyday passers-by were selected and employed in the study. The population consists of twenty five males and twenty five females. They belonged to almost all walks of life including vendors, teachers, workers, students, ordinary housewives and businessman. A structured interview was conducted among the fifty respondents guided by a specifically prepare questionnaires.

\section{Results and Discussion}

\subsection{Structure}

Table 1 implies that respondents viewed structure as very adequate. This is because DPWH personnel maintain their monitoring and supervision on the specified location through the DPWH post located along Espana, in front of University of Santo Tomas (UST).

Table 1. Frequency Distribution of Adequacy in Structure

\begin{tabular}{|l|c|c|c|c|c|}
\hline & $\begin{array}{c}\text { Very } \\
\text { adequate }\end{array}$ & Adequate & $\begin{array}{c}\text { Less } \\
\text { adequate }\end{array}$ & Inadequate & Total \\
\hline $\begin{array}{l}\text { 1. Monitoring and } \\
\text { supervision of maintenance } \\
\text { from the Regional office }\end{array}$ & 37 & 13 & 0 & 0 & 50 \\
\hline $\begin{array}{l}\text { 2. Response for the } \\
\text { implementation of the } \\
\text { project }\end{array}$ & 41 & 9 & 0 & 0 & 50 \\
\hline
\end{tabular}

\subsection{Management}

Table 2 implies that respondents indicate as adequacy both "planning and setting of goals to be followed" are adequate and "establishing of goals and procedures" are less adequate, this is due to the budgetary constraint.

Table 2. Frequency Distribution of Adequacy in Management

\begin{tabular}{|l|c|c|c|c|c|}
\hline & $\begin{array}{c}\text { Very } \\
\text { adequate }\end{array}$ & Adequate & $\begin{array}{c}\text { Less } \\
\text { adequate }\end{array}$ & Inadequate & Total \\
\hline 1. Planning & 9 & 33 & 6 & 2 & 50 \\
\hline $\begin{array}{l}\text { 2. Setting of goals to be } \\
\text { followed }\end{array}$ & 8 & 31 & 9 & 2 & 50 \\
\hline $\begin{array}{l}\text { 3. Establishment of goals } \\
\text { procedure }\end{array}$ & 4 & 6 & 35 & 5 & 50 \\
\hline
\end{tabular}

\subsection{Personnel}

Table 3 implies that respondents indicate as very adequate in "proper training and motivation of personnel involved in the project". 
Table 3. Frequency Distribution of Adequacy in Personnel

\begin{tabular}{|l|c|c|c|c|c|}
\hline & $\begin{array}{c}\text { Very } \\
\text { adequate }\end{array}$ & Adequate & $\begin{array}{c}\text { Less } \\
\text { adequate }\end{array}$ & Inadequate & Total \\
\hline $\begin{array}{l}\text { 1. Availability of the skilled } \\
\text { worker }\end{array}$ & 41 & 9 & 0 & 0 & 50 \\
\hline $\begin{array}{l}\text { 2. Proper training and } \\
\text { motivation of the personnel } \\
\text { involved in projects }\end{array}$ & 44 & 6 & 0 & 0 & 50 \\
\hline
\end{tabular}

\subsection{Financial Resources}

Table 4 implies that respondents viewed "sufficiency of financial resources" as inadequate, this may be due to the budgetary constraints that will eventually affect the implementation of the project, since the Philippines is facing the financial assistance distress due to peso devaluation.

Table 4. Frequency Distribution of Adequacy in Financial Resources

\begin{tabular}{|l|c|c|c|c|c|}
\hline & $\begin{array}{c}\text { Very } \\
\text { adequate }\end{array}$ & Adequate & $\begin{array}{c}\text { Less } \\
\text { adequate }\end{array}$ & Inadequate & Total \\
\hline $\begin{array}{l}\text { 1. Sufficient of financial } \\
\text { resources }\end{array}$ & 0 & 0 & 4 & 46 & 50 \\
\hline $\begin{array}{l}\text { 2. Availability of the funds } \\
\text { for the implementation of } \\
\text { projects }\end{array}$ & 32 & 17 & 1 & 0 & 50 \\
\hline
\end{tabular}

\subsection{Technical}

Table 5 implies that respondents viewed "personnel technical expertise and assistance, and guidance" as very adequate but it is not enable to execute model work with the aim of the technology transfer, this is due to the budgetary constraints.

Table 5. Frequency Distribution of Adequacy in Technical

\begin{tabular}{|l|c|c|c|c|c|}
\hline & $\begin{array}{c}\text { Very } \\
\text { adequate }\end{array}$ & Adequate & $\begin{array}{c}\text { Less } \\
\text { adequate }\end{array}$ & Inadequate & Total \\
\hline 1. Technical expertise & 38 & 12 & 0 & 0 & 50 \\
\hline $\begin{array}{l}\text { 2. Technical assistance and } \\
\text { guidance }\end{array}$ & 33 & 17 & 0 & 0 & 50 \\
\hline
\end{tabular}

\subsection{Maintenance and Operation}

Table 6 implies that respondents indicate as adequate in "repair and rehabilitation of the equipment, pumps, and electric motor" which may be due to the government agencies concerned which is not prioritizing the allocation of the budget, maintenance and care of the equipment. Likewise due to budgeting constraints, "actual budget for the equipment" are inadequate. Maintenance has been considerably reduce the impact of which will eventually affect the level of equipment available for the repair and maintenance. 
Table 6. Frequency Distribution of Adequacy in Repair and Rehabilitation

\begin{tabular}{|l|c|c|c|c|c|}
\hline & $\begin{array}{c}\text { Very } \\
\text { adequate }\end{array}$ & Adequate & $\begin{array}{c}\text { Less } \\
\text { adequate }\end{array}$ & Inadequate & Total \\
\hline 1. Pumps & 11 & 39 & 0 & 0 & 50 \\
\hline 2. Engines & 17 & 33 & 0 & 0 & 50 \\
\hline 3. Electric motors & 14 & 36 & 0 & 0 & 50 \\
\hline 4. Budget for the equipment & 0 & 0 & 20 & 30 & 50 \\
\hline
\end{tabular}

\subsection{Reduction of Volume of Floodwater}

Table 7 implies that respondents indicate "availability of equipment and other facilities" and, viewed "removal of sediments" as satisfactory. However, "sufficient of financial resources" as unsatisfactory, this is due to the lack of funds or budgetary allocation since the Philippines has fallen to the financial distress.

Table 7. Frequency Distribution of Satisfaction in Reduction of Volume of Floodwater

\begin{tabular}{|l|c|c|c|c|c|}
\hline & $\begin{array}{c}\text { Very } \\
\text { satisfactory }\end{array}$ & Satisfactory & Uncertain & Unsatisfactory & Total \\
\hline $\begin{array}{l}\text { 1. Availability of } \\
\text { equipment and } \\
\text { other facilities }\end{array}$ & 18 & 32 & 0 & 0 & 50 \\
\hline $\begin{array}{l}\text { 2. Removal of } \\
\text { sediments }\end{array}$ & 13 & 37 & 0 & 0 & 50 \\
\hline $\begin{array}{l}\text { 3. Sufficient final } \\
\text { resources }\end{array}$ & 0 & 0 & 9 & 41 & 50 \\
\hline
\end{tabular}

\subsection{Reduction of Flood Damage}

Table 8 implies that respondents indicate that the "improvement of the drainage will reduce damage to houses and public facilities, and private properties" as satisfactory, this is because of the contribution to the improvement in life of a large number of people.

Table 8. Frequency Distribution of Satisfaction in Reduction of Flood Damage

\begin{tabular}{|l|c|c|c|c|c|}
\hline & $\begin{array}{c}\text { Very } \\
\text { satisfactory }\end{array}$ & Satisfactory & Uncertain & Unsatisfactory & Total \\
\hline $\begin{array}{l}\text { 1. Reduce damage to } \\
\text { houses and public } \\
\text { facilities }\end{array}$ & 17 & 33 & 0 & 0 & 50 \\
\hline $\begin{array}{l}\text { 2. Reduce damage to } \\
\text { private facilities }\end{array}$ & 15 & 35 & 0 & 0 & 50 \\
\hline
\end{tabular}

\subsection{Economic Aspects}

Table 9 implies that respondents viewed the "stimulate economy through the stabilization of the people livelihood" as satisfactory. However, "restore existing drainage" is unsatisfactory; this is because of the sediments from the waste disposal that blocked the drainage which causes flooding. 
Table 9. Frequency Distribution of Satisfaction in Economic Aspects

\begin{tabular}{|l|c|c|c|c|c|}
\hline & $\begin{array}{c}\text { Very } \\
\text { satisfactory }\end{array}$ & Satisfactory & Uncertain & Unsatisfactory & Total \\
\hline $\begin{array}{l}\text { 1. Stimulate economic } \\
\text { through the } \\
\text { stabilization of the } \\
\text { people livelihood }\end{array}$ & 4 & 46 & 0 & 0 & 50 \\
\hline $\begin{array}{l}\text { 2. Restore existing } \\
\text { drainage }\end{array}$ & 0 & 0 & 9 & 31 & 50 \\
\hline
\end{tabular}

\subsection{Health}

Table 10 implies that respondents viewed "health" as satisfactory. Most of the respondents feel that dredging and undocking of the existing drains will result in the removal of the foul odor which causes the epidemics leading to the improvements of the sanitary condition for the residents.

Table 9. Frequency Distribution of Satisfaction in Health

\begin{tabular}{|l|c|c|c|c|c|}
\hline & $\begin{array}{c}\text { Very } \\
\text { satisfactory }\end{array}$ & Satisfactory & Uncertain & Unsatisfactory & Total \\
\hline $\begin{array}{l}\text { 1. Reduce epidemic } \\
\text { infection }\end{array}$ & 4 & 46 & 0 & 0 & 50 \\
\hline $\begin{array}{l}\text { 2. Raise level of } \\
\text { awareness for the need } \\
\text { of sanitation }\end{array}$ & 0 & 0 & 9 & 31 & 50 \\
\hline
\end{tabular}

\subsection{Traffic}

Table 11 perceived that "public convenience safety" is satisfactory. However, "helping to erase traffic congestion" as uncertain; this is because of heavy traffic will occur resulting from long term storm water inundation.

Table 11. Frequency Distribution of Satisfaction in Traffic

\begin{tabular}{|l|c|c|c|c|c|}
\hline & $\begin{array}{c}\text { Very } \\
\text { satisfactory }\end{array}$ & Satisfactory & Uncertain & Unsatisfactory & Total \\
\hline $\begin{array}{l}\text { 1. Help erase traffic } \\
\text { congestion }\end{array}$ & 2 & 1 & 34 & 13 & 50 \\
\hline $\begin{array}{l}\text { 2. Public convenience } \\
\text { safety }\end{array}$ & 7 & 33 & 4 & 6 & 50 \\
\hline
\end{tabular}

\section{Conclusions}

The study of the project areas has been expanding rapidly in recent years. In keeping the pace with the explosive increase in the population an increase numbers of the people have suffered from the floods during rainy seasons, which occur almost every year. This project has been organized as part of the infrastructure development project aimed on attacking problems confronting Espana Boulevard and its implementation is being sought. Improvement of existing drainage in the year around cleaning and de-siltation of drainage and estuary leading to the pumping station increases the volume of floodwaters to be pump out in the areas of responsibility of the pumping station during rainy days and flood emergencies.

The people benefiting from this project are mainly residents living in the low lying areas are commuters from neighboring cities and municipalities. This project is very 
significant since it is expected to reduce flood damage afflicting the people contribute to the improvement. The DPWH-National Capital Region shall provide personal maintenance of this project. It can be concluded that for the benefits of the populace, adequacy preparation shall be done with the proper implementation of the project.

\section{Appendix}

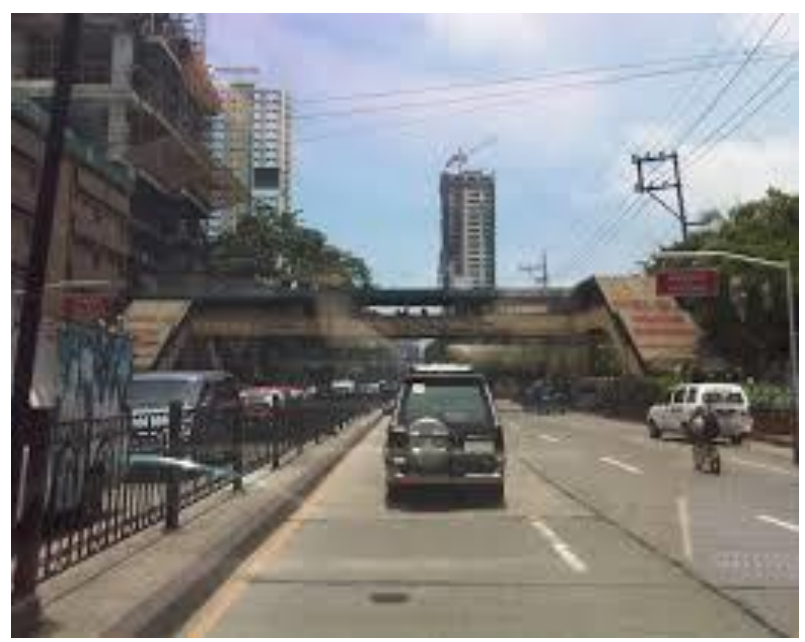

Figure 2. Espana Roads in Manila

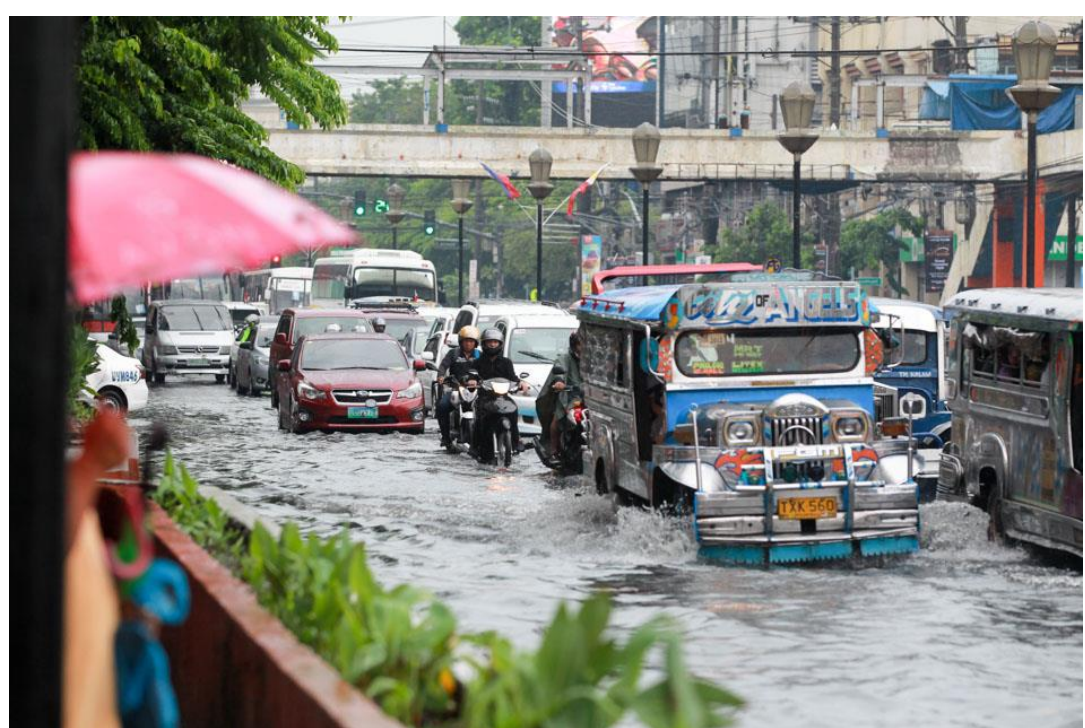

Figure 3. Flood in Espana Roads 


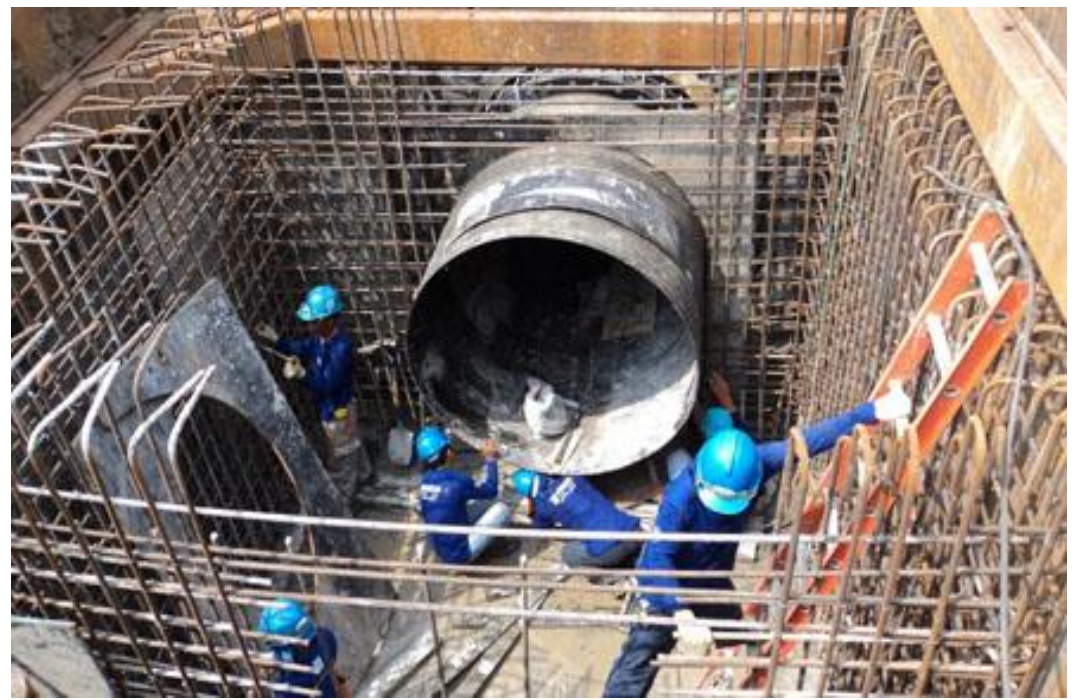

Figure 4. Supply and Discharge Pipelines for new Pasay Pump Station

\section{References}

[1] T. U. Ganiron Jr., "An Analysis of Public Perception of Floods in Manila City", International Journal of Disaster Recovery and Business Continuity, vol. 5, no. 1, (2014), pp. 1-14.

[2] T. U. Ganiron Jr, F. Aserios, M. Brigancia, M. Coderes and A. Yap, "The Gravitational Sub-Pumping Station along Riverside Road Intramuros Manila", BS Thesis, Civil Engineering Department, FEATI University, Manila, (2003).

[3] J. Gaillard, C. Liamzon and J. Villanueva, "Natural 'Disaster: A Retrospect into the Causes of the late2004 Typhoon Disaster in Eastern Luzon, Philippines", Environmental Hazards, vol. 7, no. 4, (2007).

[4] T. U. Ganiron Jr, "Perception on the Effectivity of Flood Control Pump Station in Lagusnilad underpass in Lawton", BS Thesis, Civil Engineering Department, FEATI University, Manila, (2004).

[5] E. Rivera, C. Guanzon, V. Opena, R. Papio and A. J. Hernandez, "Rehabilitation of the Drainage System and the Construction of Pumping Station that will serve as Flood Control in FEATI University for the Next Decades", BS Thesis, Civil Engineering Department, FEATI University, Manila, (2002).

[6] J. Eje and J. Gemparo, "The Traffic Congestion Problem", BS Thesis, Civil Engineering Department, FEATI University, Manila, (2002).

[7] T. U. Ganiron Jr., "Design and Management Features of Ecological Sanitation", International Journal of u- and e- Service, Science and Technology, vol. 8, no. 8, (2015), pp. 41-54.

[8] T. U. Ganiron Jr., "Recycling Concrete Debris from Construction and Demolition Waste", International Journal of Advanced Science and Technology, vol. 77, (2015), pp. 7-24.

[9] J. M. Elona, "Lagusnilad Underpass now open to Vehicles-MMDA", Philippine Daily Inquirer, Retrieved from http://newsinfo.inquirer.net/471543/lagusnilad-underpass-now-open-to-vehicles-mmda, (2013) August 21.

[10] N. Calleja, "How do you Solve a problem like Flooding on Lagusnilad?", Philippine Daily Inquirer, Retrieved from http://newsinfo.inquirer.net/472533/how-do-you-solve-a-problem-like-floodingonlagusnilad, (2013) August 22.

\section{Author}

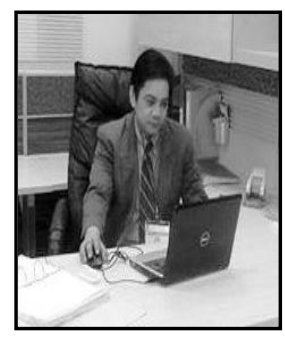

Dr. Tomas U. Ganiron Jr obtained his Doctor of Philosophy in Construction Management (2006) from the Adamson University, and subsequently earned his Master of Civil Engineering major in Highway and Transportation Engineering (1997) from the De la Salle University and received Bachelor of Science in Civil Engineering (1990) from the University of the East (Philippines). He is a registered Civil Engineer in the Philippines and Professional Engineer in New Zealand. His main areas of research interest are construction engineering, construction management, project management and recycled waste materials. He has been the resource 
person in various seminars in New Zealand (like in Auckland University of Technology, University of Auckland and University of Canterbury). He was connected with Advanced Pipeline System in New Zealand as Construction Manager wherein he supervised the sewerage and waterworks projects. He was the former Department Head of Civil Engineering in FEATI University (Manila) and former Department Head of Physics in Emilio Aguinaldo College (Manila). $\mathrm{He}$ is also very active in other professional groups like Railway Technical Society of Australasia and Australian Institute of Geoscientists where he became committee of Scientific Research He has received the Outstanding Civil Engineer in the field of Education given by Philippine Media Association Inc. (1996), ASTM Award CA Hogentogler (2008) by International Professional Engineers in New Zealand (IPENZ) and Outstanding Researcher (2013) in AlQassim University, College of Engineering. On the second week of June 2015, Dr. Ganiron was included in the Ranking of Scientists in Saudi Arabia and New Zealand institutions according to Google Scholar Citation public profile (http://www.webometrics.info/en/node/81). 
International Journal of Disaster Recovery and Business Continuity Vol.6 (2015) 